原著論文

レトロトランスポゾンを利用したサツマイモ加工品の原料品種判定

大江夏子 ${ }^{1)} \cdot$ 田原 $\quad$ 誠 $^{1)} \cdot$ 山下裕樹 ${ }^{1)} \cdot$ 丸谷 優 $^{1)} \cdot$ 蔵之内利和 2$)$

(1) 岡山大学農学部, 岡山市, $=700-8530,{ }^{2}$ 独立行政法人農業・生物系特定産業技術研究機構作物研究所, つくば市，（３05-8518）

\section{摘 要}

蒸切干し用に開発されるサッマイモ新品種の不正使用 や海外流出に対抗する手段を確立するため, 加工品であ る蒸切干し製品から，その原料となった品種を，DNAの 多型を基に高精度に判定する技術を開発することとし た. 転移因子であるレトロトランスポゾンは, 植物のゲ ノムに多数の複製配列が散在している. サツマイモのレ トロトランスポゾン Rtsp-1 のゲノム挿入部位を，葉から 抽出した DNA を用い，蒸切干し用新品種候補を含む 12 品種について S-SAP (Sequence-Specific Amplification Polymorphism）法により分析した結果，多数の複製配列 の挿入と挿入部位の品種間の多型が検出された．品種間 で違いが見られた Rtsp-1 挿入部位の塩基配列を調へ，挿 入を受けた宿主側の配列と Rtsp-1 の末端反復配列間の PCRによって, それぞれの品種について様々な挿入部位 における挿入の有無を調へたた. その結果, 最少 5 力所の 挿入部位の PCR により, 上記 12 品種の区別が可能で あった. 蒸切干しイモの DNA は, イオン交換樹脂カラム を用いて抽出することができたが，加工による断片化が 進んでいた. 断片化した蒸切干しイモの DNA を鋳型に した PCR においても，明瞭な結果が得られ，原料品種の 識別が可能であった. 染色体の特定部位におけるレトロ トランスポゾン挿入の品種間多型を PCR により判定し 品種識別を行う方法は, DNA が断片化した加工品の分析 に適する, 再現性が高く操作が容易, マーカー数の確保 が容易などの利点があり, 高次倍数性の作物や加工品な どにおける優れた品種識別マーカーとなる.

キーワード：Ipomoea batatas, レトロトランスポゾン, DNAマーカー，品種識別，サツマイモ，甘 しょ

\section{緒 言}

サッマイモ (Ipomoea batatas (L.) Lam) の用途の一つと して，「蒸切干し甘しょ」がある。最近，安価な中国産の

編集委員 : 廣近洋彦

2004 年 3 月 28 日受領 2004 年 7 月 1 日受理

Correspondence: tahara@cc.okayama-u.ac.jp
輸入量が増加し, 国内生産は厳しい状況に追い込まれて いる. この輸入量増加は，わが国の蒸切干し用主力品種 であるタマユタカ（1959 年育成）の導入により，製品の 品質改善がなされたことが主因であるとされている。 こ のような事態に対応寸るためには，わが国の蒸切干し甘 しょ生産の市場競争力を向上させることが必要であり, 国内産品の一層の品質向上による輸入品との差別化が提 唱されている。 また，タマユタカには，年次によっては， 蒸切干しに「シロタ」とよばれる不透明な白い濁りが 生じ，その部分の食感が劣る障害が発生する（猪飼ら 2002）。このため, 独立行政法人農業・生物系特定産業 技術研究機構作物研究所を中心に，タマユタカに代わる より良質な加工用新品種の開発と加工技術の向上に向け ての研究が進められている.

新品種育成者の権利は, 植物品種保護制度が整備され, 国際的にも保護されている（野澤 2004）。しかし，サッ マイモは, 栄養繁殖性で苗の増殖が容易であり,さらに, 植物体の形態形質から䛊りなく品種を特定することは困 難であり，加えて，加工品から，その原料となった品種 を判定する技術も開発されていない。このため，蒸切干 乙用に開発される新品種が国内生産者拈よび加工業者に 有効に活用され，これによって，国内産品の一層の品質 向上と輸入品との差別化を実現するためには，加熱・乾 燥加工品である蒸切干し製品から，その原料となった品 種を高精度に判定する技術を開発し，新品種の不正使用 や海外流出に対抗する手段をあらかじめ確立しておく必 要がある。

最近，品種育成者の権利侵害の取り締まりや品種表示 の不正防止などのために，DNA の多型検出法による品種 識別技術が注目されている. 識別技術としては, RFLP（Restriction Fragment Length Polymorphism)，RAPD（Random Amplified Polymorphic DNA), AFLP (Amplified Fragment Length Polymorphism), SSR (Simple Sequence Repeat), CAPS (Cleaved Amplified Polymorphic Sequence), ISSR (InterSimple Sequence Repeat), SNP (Single Nucleotide Polymorphism）などが検討されて拈り（矢野 2004），イネ，イ グサ，イチゴ，インゲンなどでは，上記の方法を用いた ものが実用化されている。 しかし，サッマイモについて は，ゲノム解析が進んでいないこともあり，DNAによる 品種識別技術はいまだ開発されていない.

レトロトランスポゾンは，ゲノム中を転移する因子で ある. 転移は, ゲノム中の配列が転写された後, 逆転写 
反応により元の配列の複製となった DNA がゲノムに挿 入されるという過程をとり，一旦挿入された配列は安定 的に遺伝する (Kumar and Bennetzen 1999). 植物ゲノム には，進化の過程でこのようにして複製された配列が多 数存在するが，そのほとんどは，転移活性を失っている. イネとタバコに拈いては，通常は静止状態であるが，力 ルス化や病原菌の感染など植物体にストレスがかかると 転移する配列が見出されている (Grandbastien et al. 1989, Hirochika 1993, Hirochika et al. 1996).

レトロトランスポゾンの複製配列はゲノム中に多数散 在しており，優れた遺伝子マーカーとなることが知られ ている (Flavell et al. 1998, Kumar and Hirochika 2001, Waugh et al. 1997)。 また，レトロトランスポゾンをマル チローカスプローブとして用いると，日本型イネ 6 品種 とインド型イネ 6 品種のすべての品種同定が可能であっ たことから，各種植物から単離されるレトロトランスポ ゾンは，DNA フィンガープリンティングに有効である ことが示唆されている (Fukuchi et al. 1993).

サッマイモのレトロトランスポゾンについては，最近， カルスに扔いて転移するLTR (Long Terminal Repeat：末 端反復配列）型レトロトランスポゾン配列（Rtsp-1）が サッマイモ・ゲノムから同定された（Tahara et al. 2004）. Rtsp-1 は，ゲノム中に 400 個前後の複製配列が存在する が，転移活性を失っていない配列も存在するので，サッ マイモが種として成立した後に転移した配列も多くある ものと考兄られる．複製配列が挿入されるゲノム側の配 列には規則性がなく，このようにして生じた複製配列の 挿入は，特定の染色体の特定の場所にの久見られること となり，後代に遺伝すれば，派生形質となる。 そこで染 色体上の様々な場所に扣ける派生形質となった挿入がぞ のような組み合わせになっているかを調べることで，精 度の高い品種識別が可能であると想定される.

ゲノムに打けるレトロトランスポゾンの個々の挿入位 置は，制限酵素処理末端へのアダプター付加法（S-SAP： Sequence-Specific Amplification Polymorphism 法)（Waugh et al. 1997）により，挿入位置近傍のゲノム配列（制限酵 素認識部位) と LTR 配列間の PCR (Polymerase Chain Reaction）増幅により区別できる。本報告では，S-SAP 法に おいて品種間多型を検出したRtsp-1 レトロトランスポゾ ンの挿入部位をクローニングし，決定した塩基配列に基 づき設計したプライマーを用いて PCR を行い，各品種に ついて，それらの染色体の位置に打ける挿入の有無を判 定することにより, 蒸切干し用の品種を識別し,さらに, 干しイモから抽出した DNA を基に原料となった品種を 同定する方法について検討した.

\section{材料および方法}

\section{1. 材料}

サッマイモ品種としては, タマユタカ, タマオトメ, 泉
13 号, 沖縄 100 号, 宇薯 2 号, 烟薯 6 号, ヘルシーレッ ド，関東 119 号，関東 120 号，九州 122 号，九州 127 号， 九州 139 号抢よび高系 14 号を用いた。 タマユタカ，タマ オトメ，ヘルシーレッドは日本の蒸切干し用の育成品種 で，泉 13 号は古くから蒸切干しに用いられてきた日本 の在来品種である. 沖縄 100 号は戦前の日本の育成品種 で，戦中期に中国に導入され，「勝利 100 号」として中国 で普及するとともに，多くの中国品種の交配親となった 品種である．宇薯 2 号，烟薯 6 号は中国品種である．関 東 119 号, 関東 120 号, 九州 139 号は蒸切干し用新品種 の候補系統で，九州 122 号打よび九州 127 号は，これら の交配母本として利用されている系統である。高系 14 号はS-SAP 産物のクローニングに用いた。 また，タマユ 夕力, 泉 13 号, 沖縄 100 号, 宇薯 2 号, 畑薯 6 号, ヘル シーレッド怙よび関東 120 号については, 蒸切干しイモ の分析も行った．な抢，蒸切干しイモは，90 分間の蒸し 煮（約 $100^{\circ} \mathrm{C}$ の加熱）の後, 温度約 12 度, 湿度約 $30 \%$ で 5 日間乾燥して作成したものを用いた.

\section{DNA 抽出}

植物体のゲノム DNA は, CTAB (cetyltrimethylammonium bromide）法（早川 1997）を基本に，新鮮な葉 $100 \mathrm{mg}$ か ら抽出した．蒸切干しイモからのゲノム DNA は，「遺伝 子組換光食品の検査と分析のマニュアル」(JAS 分析試 験ハンドブック 2002）に従い，イオン交換樹脂カラム （QIAGEN Genomic-tip 20/G）を用いて $2 \mathrm{~g}$ のてイモか ら抽出した．対照とするため，加工処理を行っていない 沖緡 100 号の塊根の内部組織から，干しイモと同様の方 法で DNA を抽出した。 いずれの抽出試料も RNaseA 処 理により RNAを分解した。な拉，アガロースゲル電気泳 動により，蒸切干し加工による DNA の断片化の程度を確 認した

\section{3. 制限酵素処理末端へのアダプター付加法（S-SAP 法）} サッマイモの各品種の葉から抽出したゲノム DNA $5 \mu \mathrm{g}$ を, 制限酵素 Mse I $2 \mathrm{U}$ を含み $50 \mu \mathrm{l}$ 飞定容した反応液 $(50$ $\mathrm{mM}$ 塩化ナトリウム, $10 \mathrm{mM}$ トリス塩酸（Tris- $\mathrm{HCl}, \mathrm{pH}$ 7.9), $10 \mathrm{mM}$ 塩化マグネシウム $\left(\mathrm{MgCl}_{2}\right), 1 \mathrm{mM}$ ジチオ

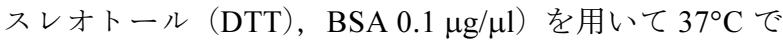
12 時間反応させた後, $65^{\circ} \mathrm{C}$ で酵素を失活させた。 $\mathrm{PCI}$ (フェノール：クロロホルム：イソアミルアルコール= $25: 24: 1)$ 処理により, 制限酵素を除き,さらにェタノー ル沈殿により, DNAを精製し, 最終的に $50 \mu \mathrm{l}$ の TE 緩衝 液に溶解した

次に，制限酵素処理したゲノム DNA にアダプターを 付加した. アダプターは 2 種類のオリゴヌクレオチド（5'GACGATGAGTCCTGAG-3' と 5'-TACTCAGGACTCAT3')をそれぞれ $1 \mathrm{nmol}$ ずつ混合後，アニーリングさせて 準備した.アダプターの付加は, 制限醥素処理産物 $10 \mu \mathrm{l}$ にアダプター $15 \mathrm{pmol}, \mathrm{T} 4 \mathrm{DNA}$ Ligase $1 \mathrm{U}$ を加え $20 \mu \mathrm{l}$ に 
定容した反応液 (50 mM Tris-HCl (pH 7.5), $10 \mathrm{mM} \mathrm{MgCl}_{2}$,

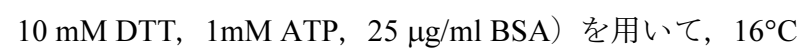
で 2 時間インキュベートして行った.

次に, ライゲーション産物を鋳型として PCR 増幅を 行った. Rtsp-1 の内部配列による増幅を避け，5'末端と それに繋がるゲノム配列を選択的に増幅するため, seminested PCR を行らこととし, LTR 特異的プライマーとし て, Rtsp-1 の 5' 側 LTR 配列内側の PBS (primer binding site) 領域を含むPBS_comp プライマー(5'-CAGAAGGCT CTGATACCAATTGTTGCGC-3'） とその約 $150 \mathrm{bp}$ 上流の LTR 領域を含み, $5^{\prime}$ 末端を TexasRed で標識した Ext_R プ ライマー（5'-CCACTCTCTAACTAACAAGGAG-3'）を準 備した。 また，アダプター用のプライマーとして, Mse I プライマー（5'-GACGATGAGTCCTGAGTAA-3'）を準備 した.

1 回目の PCR 反応は Mse I と PBS_comp プライマーで 行った. 反応は, $10 \mu \mathrm{l}$ の反応液を, ライゲーション産物 $2 \mu \mathrm{l}$, Taq DNA Polymerase 0.5 U (Sigma 社製), $10 \mathrm{mM}$ Tris- $\mathrm{HCl} \mathrm{pH} 8.3,50 \mathrm{mM}$ 塩化カリウム, $2.5 \mathrm{mM} \mathrm{MgCl}_{2}$, $200 \mu \mathrm{M} \mathrm{dNTPs}$, 各プライマー $0.4 \mathrm{pmol}$ を含むように調整 乙, $94^{\circ} \mathrm{C} 4$ 分間の変性, $94^{\circ} \mathrm{C} 1$ 分間 $\cdot 63^{\circ} \mathrm{C} 1$ 分間. $72^{\circ} \mathrm{C}$ 2 分間を 30 サイクル, $72^{\circ} \mathrm{C} 5$ 分間の最終伸張反応のサイ クリング条件で行った. semi-nested PCR に相当する 2 回 目の PCR は, 鋳型として 1 回目の反応液の 1000 分の 1 量 をまたプライマーとして，5'末端をTexasRed で標識し たExt_R プライマーと Mse I プライマーの $3^{\prime}$ 末端にアデ ニン 1 塩基を付加したプライマーを用いて，これ以外の 反応液組成は 1 回目のものと同じとして実施した。 サイ クリング条件は, アニーリング温度を $54^{\circ} \mathrm{C}$ に変更した以 外は 1 回目と同じとした。増幅産物は $95^{\circ} \mathrm{C} 2$ 分間の処 理で変性させ，氷中に挿して急冷し，そのらちの $2 \mu \mathrm{l}$ に loading dye (94\% ホルムアミド, $10 \mathrm{mM}$ EDTA, $0.5 \mathrm{mg} / \mathrm{ml}$ ブロモフェニル・ブルー) $0.5 \mu \mathrm{l}$ を加えて電気泳動のサン プルとした．電気泳動は，6\%変性ポリアクリルアミド ゲルを装着したSQ-5500 DNA Sequencer（日立製）で実 施した.

\section{S-SAP 増幅産物のクローニングとシークェンス}

タマユタカを鋳型とした S-SAP 増幅産物をクローニ

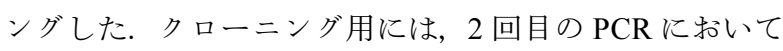
TexasRed 標識を行っていないExt_R プライマーを用い た. S-SAP 分析の結果, $350 \sim 450 \mathrm{bp}$ の領域に品種間多 型を示す断片が多く観察され，この長さは，LTRの長さ から見て, Rtsp-1 がサッマイモのゲノムに挿入された部 分に近接する宿主側の配列に相当するので，アガロース 電気泳動を行い，この長さに相当するゲルの部分を切り 出し, QIAquick Gel Extraction kit（QIAGEN 社製）を用い て DNAを精製した. 精製したDNAは, TOPO TA Cloning kit (Invitrogen 社製) を利用してクローニングした. 形質 転換された大腸菌コロニーの菌体を鋳型に, S-SAP の 2
回目と同じPCRを行い, 熱変性後, タマユタカの S-SAP サンプルとともにシーケンス・ゲルにかけてプラスミド に挿入された DNAのサイズを調査した。電気泳動の結 果, S-SAP 分析に拈いてタマユタカ以外の一部の品種で は増幅が見られなかった断片と一致するものが挿入され た大腸菌のコロニーを選定した. 高系 14 号の DNA につ いても, タマユタカの場合と同様の方法で S-SAP 増幅産 物をクローニングし, 蒸切干し用の品種間で多型を示す と見られた断片と一致するものが抻入されたコロニーを 選定した。 選定したコロニーは，LB 培地を用いて $37^{\circ} \mathrm{C}$ で 18 時間振盪培養後, プラスミドDNAを抽出した.

シーケンスは, BigDye Terminator Cycle Sequencing FS Ready Reaction Kit（Applied Biosystems 社製）で反応を行 い, ABI PRISM ${ }^{\mathrm{TM}} 310 \mathrm{NT}$ Genetic Analyzer で分析した.

\section{5. 同定した S-SAP 配列による PCR 増幅}

塩基配列を決定した S-SAP 増幅産物の宿主側の配列 に, LTR 配列上の Ext_R プライマーと PCR 増幅が可能 になる向きにプライマーを設計した. これらのプライ マーとExt_R プライマーを用いて, 各品種の葉および蒸 切干しイモから抽出したゲノム DNA を鋳型に PCR 増幅 を行った. PCR 反応液組成は，鋳型をゲノム DNA20 ng とし，プライマー（0.4 pmol）を変更した以外は S-SAP 反応のものと同じとした. 反応は $94^{\circ} \mathrm{C} 4$ 分間の変性の後, $94^{\circ} \mathrm{C} 1$ 分間 $\cdot 57^{\circ} \mathrm{C} 1$ 分間 $\cdot 72^{\circ} \mathrm{C} 1$ 分 30 秒間を 30 サイク ル, $72^{\circ} \mathrm{C} 5$ 分間の伸長反応で行った. 増幅産物はアガロー スゲルで電気泳動し，エチジウムブロマイドで染色して 観察した。な拈，それぞれの葉または干しイモから抽出 したDNA は, 一つのバッチとして調整し, そのバッチ を全ての PCR の鋳型として用いた. その結果，いずれの 試料も 1 種類以上の PCR に扣いて増幅が見られたので, 増幅が見られなかった種類の PCRについては, 当該試料 に, その PCR のプライマー組み合わせによって増幅する 宿主配列と LTR 配列の接続部が存在しなかったと判断 した.

\section{結 果}

\section{1. 蒸切干しイモから抽出した DNA}

蒸切干し加工による DNA の断片化の程度を調査するた め, 蒸切干しイモから抽出したDNA について, 加工処 理を行っていない沖縄 100 号の塊根から抽出した DNA を対照としてアガロースゲルを用いて電気泳動した結果 は, 図 1 に示した. 加工処理を行っていない塊根から抽 出した DNA は高分子の状態であるが，干しイモからの ものは，汇とんど 500 bp 以下に断片化していた.なお, $260 \mathrm{~nm}$ の吸光度により抽出された DNA を定量すると, $2 \mathrm{~g}$ の生イモ (塊根内部組織) からは $104 \mu \mathrm{g}, 2 \mathrm{~g}$ の干し イモからは平均約 $21 \mu \mathrm{g}$ であった。 


\section{S-SAP 分析}

蒸切干し用の従来品種，新品種候補とその母本品種な ぞについて，Rtsp-1 レトロトランスポゾンのゲノムにお ける挿入部位の品種間多型を明らかにするため，Rtsp-1 の LTR 配列を利用した S-SAP 法による分析を行った. その結果, 各品種に多数の増幅産物が得られ，また，品 種間で明瞭な多型が検出された（図 2)。使用したLTR プライマー（Ext_R）から LTRの 5' 末端までの長さは,

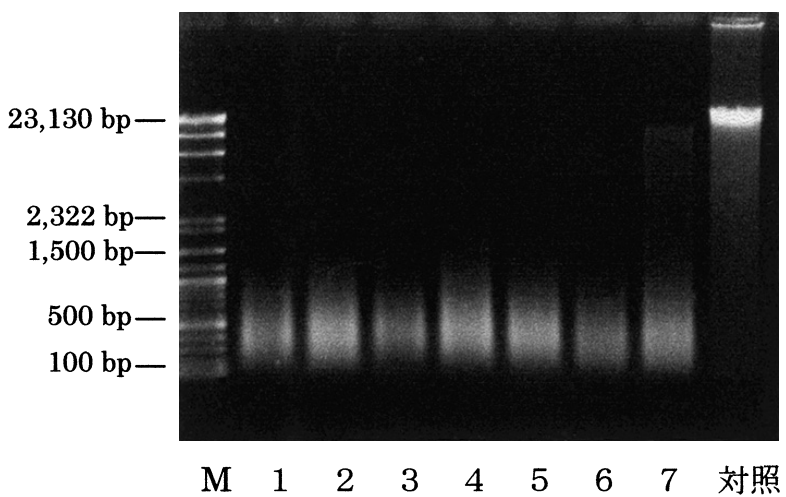

図 1. サッマイモの蒸切干し甘しょから抽出した DNA の電気 泳動像

M: サイズマーカー（100 bp ラダー + DDNA の Hind III カッ ト) 1 : ヘルシーレッド, 2 : 畑薯 6 号， 3 : 宇薯 2 号, 4 : タマユタカ, $5:$ 関東 120 号, $6:$ 泉 13 号, $7:$ 沖縄 100 号, 対照 : 沖縄 100 号の生イモからの抽出
サッマイモのカルスで転移していた配列（Tahara et al. 2004) では, 311 bp であり, それよりも長い断片は, Rtsp1 がサッマイモのゲノムに挿入された場所に扣いて，宿 主側の配列に存在する直近の制限酵素（Mse I）認識部位 までの長さの違い，すなわち，挿入場所の違いを反映し ているものと推定された.

\section{S-SAP 配列による PCR 増幅}

タマユタカの S-SAP 増幅産物のらち，350〜450 bp に 相当するものをアガロースゲル電気泳動により精製後ク ローニングし，大腸菌に形質転換した。この大腸菌のコ ロニーについて，プラスミドに挿入された断片を S-SAP 分析の方法に従って増幅と同時に蛍光標識し, タマユタ カの S-SAP 産物と共にシーケンス・ゲルで電気泳動した 結果，コロニーごとに，S-SAP 増幅産物のどの断片が挿 入されているかを判定できた（図 3).S-SAP 分析を含 め, 電気泳動により分離する断片は，従来，ブロッティ ングによりゲルからメンブレンに DNA を移動後固定し, 目的とする DNA の断片が含まれるメンブレンの部分の DNA を対象にPCRを用いて増幅し，クローニングに供 していた．このような方法と比べ，本報告の方法は，操 作が簡単であり，さらに，目的とする断片がクローニン グされているコロニーを確実に選抜できる．高系 14 号 の S-SAP 増幅産物をクローニングしたコロニーについ ても同様の調査を行い，蒸切干し用の品種間で多型を示
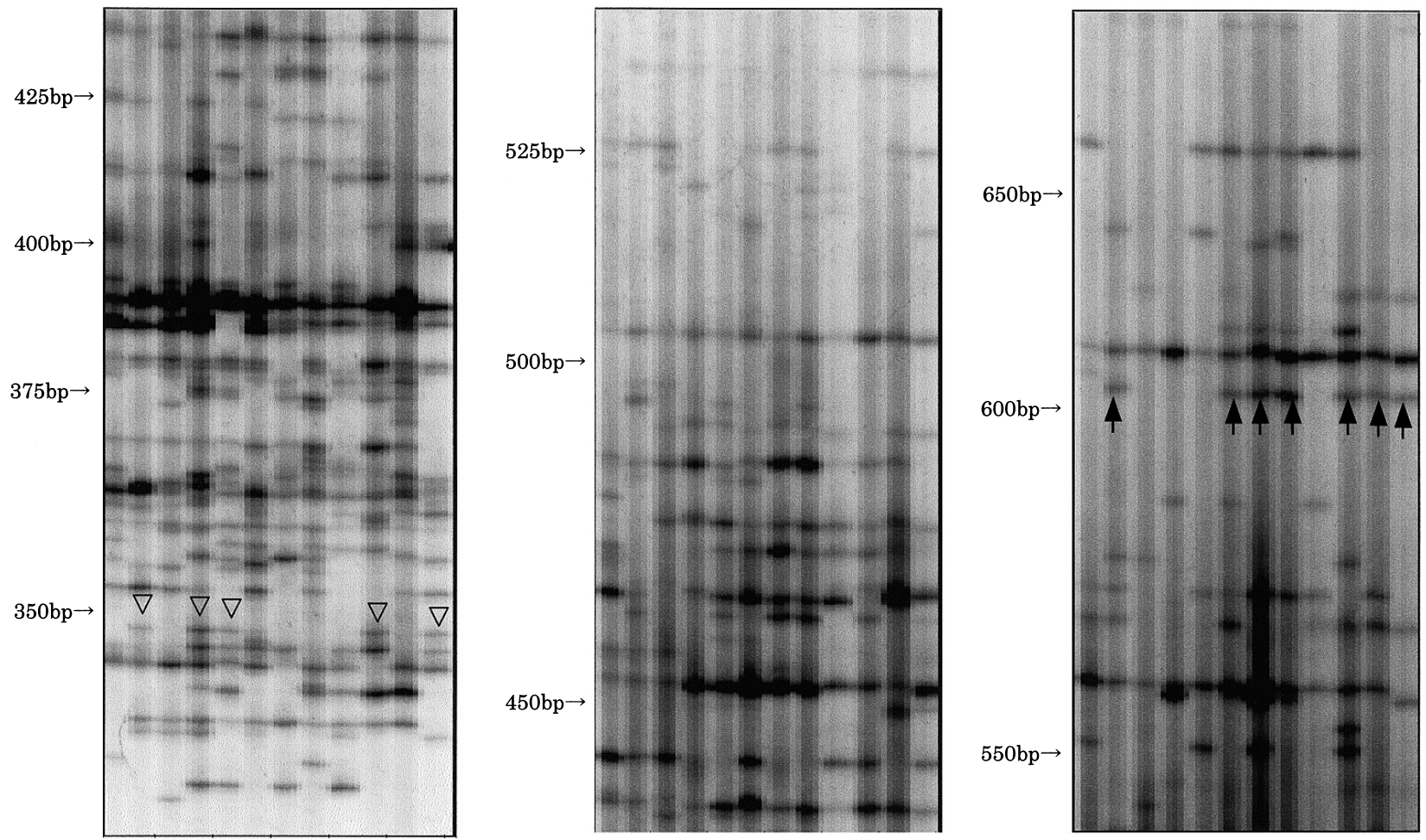

図 2. Rtsp-1 レトロトランスポゾンの LTR 配列を利用したサッマイモ品種の S-SAP 分析

レーンは, 左から, ヘルシーレッド, 畑薯 6 号, 宇薯 2 号, タマユタカ, タマオトメ, 関東 119 号, 関東 120 号, 九州 122 号, 九州 127 号，九州 139 号，泉 13 号，沖縄 100 号. S2 Rev（AB167517）括よび SRNRN（AB167520）を用いたPCRの多型の結 果（表 2）は，それぞれ，白抜きの三角形（347 bp）抢よび矢印（610 bp）で示す S-SAP 断片の多型と一致する. 


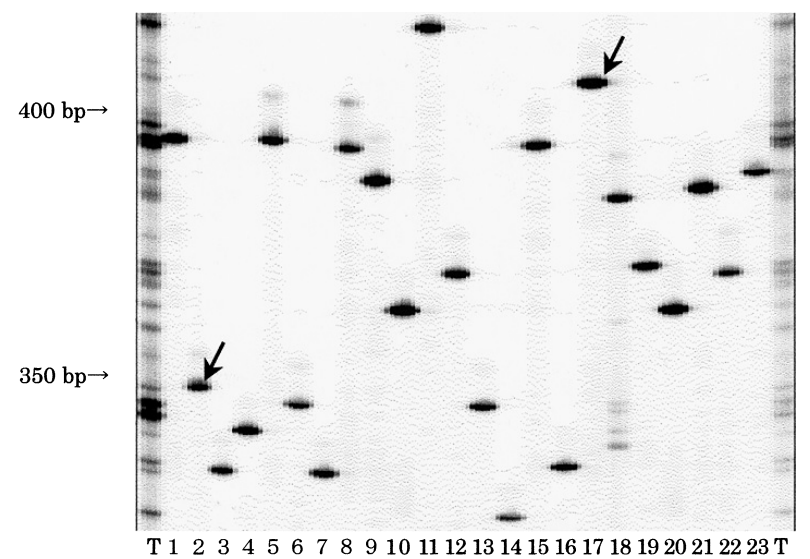

図 3. S-SAP 法の蛍光染色を利用した大腸菌コロニーのプラス ミドインサート・チェック（タマユタカの S-SAP 増幅産 物をクローニングしたもの)

$\mathrm{T}$ : タマユタカの S-SAP 増幅産物, $1 \sim 23$ : タマユタカの S-SAP 増幅産物をインサートしたプラスミドで形質転換 した大腸菌コロニーの番号

矢印で示した 2 と 17 のコロニーのインサートは, 蒸切 干し甘しょ品種の間で多型が見られた S-SAP 産物と長さ が一致したので，塩基配列を決定した（左が：AB167517: 347 bp，右が AB167518: 402 bp).
すとみられるインサートについて塩基配列を決定し，宿 主側の塩基配列にプライマーを設計した（表 1)。これら のらち，S17_Revを設計した配列（AB167518）を図4に 示した. 一般に, LTR 配列の $5^{\prime}$ 末端は, TG で開始される が，表 1 の-SAP 産物の配列については, Ext_R プライ マーとそれに隣接する部分の注か， $3^{\prime}$ 末端から $310 \mathrm{bp}$ 程 度の部分に， 5'-TGTC (A/G) GCA-3' からなる保存配列 が存在した.一方，これよりも上流の部分では，表 1 の配 列間で相同性が見られなかったので，この保存配列が Rtsp-1 の LTR の 5' 末端であり，それよりも上流部分は, Rtsp-1 が転移・挿入したゲノム配列であると判断した. な お，Rtsp-1 の LTR の全長配列は，別の実験によりクロー ニングを行っているが，5'末端側のU3 (Unique at 3') 領 域では配列が多様である一方， R (Repeated terminus of a transcript）扎よび 3' 末端の U5（Unique at 5'）領域では 配列が非常に高く保存されていた．また，タバコで見出 された転移活性を有するTnt1に颃いても, U3 領域の配 列は R 領域と比べて多様であることが示されている (Vernhettes et al. 1998).

表 1 のプライマーと LTR 配列上の Ext R プライマー を用いて，それぞれの品種の葉から抽出したゲノム DNA を鋳型として PCR を行った結果, S-SAP 増幅産物の塩

表 1. サッマイモ品種間で多型（増幅の有無）が生じた S-SAP 増幅産物とその配列を基に設計した品種識別用 PCR プライマー

\begin{tabular}{|c|c|c|c|c|}
\hline アクセッション番号 1) & $\begin{array}{c}\text { 断片長 } \\
\text { (bp) }\end{array}$ & プライマー名 & プライマー塩基配列 & $\begin{array}{l}\text { 増幅断片長 } \\
\text { 期待値 (bp) }\end{array}$ \\
\hline AB167512 & 433 & KB4-7GS1 & 5'-TGGCAGGAAACCTCAACTTTTACTGG-3' & 373 \\
\hline AB167513 & 437 & KB4-8GS1 & 5'-TGGCATAGTGTGTAACTTCTTCTATC-3' & 416 \\
\hline $\mathrm{AB} 167514$ & 412 & KB4-20GS1 & 5'-TCGCAGCCATCAATACCTTCTA-3' & 352 \\
\hline $\mathrm{AB} 167515$ & 436 & KB4-22GS1 & 5'-CCTATGTTGTTAGTTAGGGGGG-3' & 355 \\
\hline AB167516 & 385 & KB4-24GS1 & 5'-TGGAGTTTTGATCAGAAGGACC-3' & 338 \\
\hline $\mathrm{AB} 167517$ & 347 & S2_Rev & 5'-AAAAGGTTGAGTTTAGCATTGTCGG-3' & 330 \\
\hline $\mathrm{AB} 167518$ & 402 & S17_Rev & 5'- ATATTGTGCAAAGTATTTGAAAACTCTAAGAG -3' & 383 \\
\hline $\mathrm{AB} 167519$ & 383 & S40_Rev & 5'- GGCTTTCTGCAAAATTGGGACT-3' & 355 \\
\hline AB167520 & 610 & SRNRN & 5'-ATAGTGGCAGTGTGTATAAATATATACTACG-3' & 591 \\
\hline
\end{tabular}

1) 日本 DNA データバンクに打ける登録番号.

$\frac{\text { GACGATGAGTCCTGAGTAAATATTGTGCAAAGTATTTGAAAACTCTAAGAGTATA }}{\text { MseI+A プライマー Rev プライマー }}$
ACATGAAAGGGGCTCAACATCCTTGGAAGTGTCGGCAGAATTATGTTGCAGCAGC
CATAATTAGGCAAATATCATCATTTGACAAAGATTAGGCAAGTCAAAAGGAGTTA
GGCATGGAGTTAGGCACCTACCAAAATATTTATTATTTGGTCCCTAAACTTTGGA
CTAACTACAAAATGACCCCTATTCCTCAACTATAAATAGGGAGGTCATTTGCCAA
TCTTGTCATCCCAAATCATTCTATTCTTCCCTCATATACTAGAGATATTAGAGAG
TTTGTTGAGTGTATTTCTCCTTCCTAGCAAGAGAGAATTATCCTTGTTTTCTCCT
TGTTAGTTAGAGAGTGG

Ext_R プライマー

図 4.クローニングした S-SAP 増幅産物の塩基配列（AB167518）とプライマー（S17 Rev）設計部位

下線部は，それぞれのプライマーの位置を，網掛け部は，LTR（Long Terminal Repeat）部位を示す。LTR 配列のらち，囲み線 部は，U3（Unique at 3'）領域を，それ以外の部位は R（Repeated terminus of a transcript）領域を示す. 
基配列から予想された長さの断片が増幅する品種と増幅 しない品種が見られた（図 5 および表 2)。増幅が見られ ない品種は, ゲノム上のゲノム配列が特定された位置に, Rtsp-1 の挿入がないことを示す．このよらな品種間の多 型は, S2_Rev (AB167517: 383 bp) や SRNRN (AB167520:

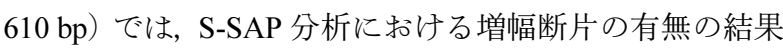
と一致し（図 2)，KB4-22（AB167515: 436 bp), S17_Rev (AB167518: 402 bp）㧊よびS40_Rev（AB167519: 383 bp） でも増幅について，品種間での違いが観察されたが，他 の増幅断片では, S-SAP 分析の増幅断片の有無と関連づ けることが困難であった。

表 1 の 9 種類の配列のらち, 最少 5 種類 (KB4-7GS1, KB4-8GS1, S17_Rev, S40_Rev 打よびSRNRN) の PCR 増 幅産物の有無の組み合わせにより, 蒸切干し関係の 12 品種の区別が可能である（表 2)。さらに，これら 9 種類 のプライマー組久合わせについて, 蒸切干しイモから抽 出した DNA を鋳型にPCR を行った結果, 葉から抽出し た DNA を鋳型とした場合と同じ長さの PCR 産物の増幅 が見られ，また，葉から抽出したDNA に抢いて増幅が見 られた品種では，干しイモから抽出した DNA でも増幅 が見られた（図 5).

\section{考 察}

LTR 配列を利用した S-SAP 分析により，蒸切干し関 係のサッマイモ品種それぞれに多数の Rtsp-1 複製配列 の插入が検出されるとともに，品種間で明瞭な多型を検 出することができた．また，Rtsp-1 挿入部位を增幅する PCR で挿入の有無を判定することにより，DNA が断片 化された干しイモに扔いても品種識別が可能であった. このため, レトロトランスポゾンについて，染色体の特 定の部位に抢ける挿入の有無を PCR 増幅によって判定 し，その結果を組み合わせることで品種を特定する方法 は，新たな品種識別の手段として活用できるものと考兄 る.これまでに, サッマイモのゲノムから，30 カ所を超 えるRtsp-1 の挿入部位をクローニングしており，今後の
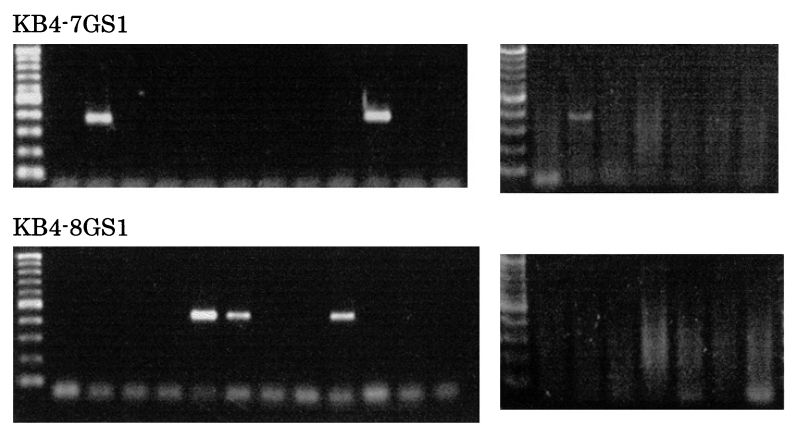

KB4-20GS1
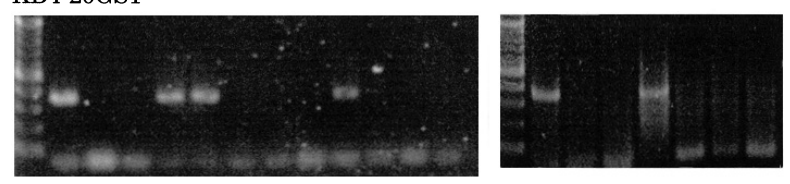

KB4-22GS1
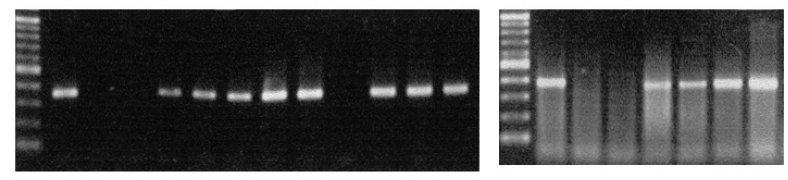

S40_Rev

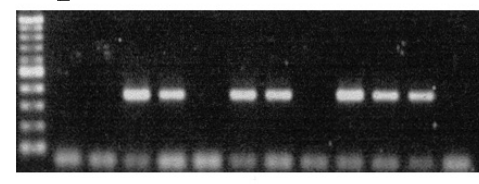

$M$ (1) (2) (3) (4) (5) (6) (7) (8) (9) (11) (11) (12) 葉から抽出した DNA を鋳型

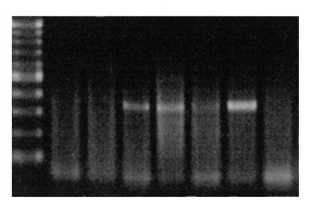

M (1) (2) (3) (4) (7) (11) (12) 干しイモから抽出した DNA を鋳型

図 5. S-SAP 増幅産物の配列を基に宿主上の配列に設計したプ ライマー(KB4-7GS1, KB4-8GS1, KB4-20GS1, KB4-22GS1 およびS40_Rev）とレトロトランスポゾンRtsp-1 の末端 反復配列上のプライマー (Ext_R) による PCR 増幅の品種 間多型

M: サイズマーカー (100 bp ラダー), (1)へルシーレッド, (2)畑薯6号, (3)宇薯 2 号, (4)タマユタカ, (5)タマオトメ, (6)関東 119 号, (7)関東 120 号, (8)九州 122 号, (9)九州 127 号, (10九州 139 号, (11)泉 13 号, (12)沖縄 100 号

表 2. サッマイモ品種間で多型（増幅の有無）が生じたS-SAP 増幅産物の配列を基に宿主上の配列に設計したプライマーとレトロト ランスポゾン Rtsp-1 の末端反復配列上のプライマーによる PCR 結果

\begin{tabular}{|c|c|c|c|c|c|c|c|c|c|c|c|c|}
\hline $\begin{array}{l}\text { プライ } \\
\text { マー名 }\end{array}$ & $\begin{array}{c}\text { ヘルシー } \\
\text { レッド }\end{array}$ & $\begin{array}{l}\text { 畑薯 } \\
6 \text { 号 }\end{array}$ & $\begin{array}{l}\text { 宇薯 } \\
2 \text { 号 }\end{array}$ & $\begin{array}{l}\text { タマ } \\
\text { ユタカ }\end{array}$ & $\begin{array}{l}\text { タマ } \\
\text { オトメ }\end{array}$ & $\begin{array}{c}\text { 関東 } \\
119 \text { 号 }\end{array}$ & $\begin{array}{c}\text { 関東 } \\
120 \text { 号 }\end{array}$ & $\begin{array}{c}\text { 九州 } \\
122 \text { 号 }\end{array}$ & $\begin{array}{c}\text { 九州 } \\
127 \text { 号 }\end{array}$ & $\begin{array}{c}\text { 九州 } \\
139 \text { 号 }\end{array}$ & $\begin{array}{c}\text { 泉 } \\
13 \text { 号 }\end{array}$ & $\begin{array}{c}\text { 沖縄 } \\
100 \text { 号 }\end{array}$ \\
\hline KB4-7GS1 & & $\bigcirc^{1)}$ & & & & & & & & $\bigcirc$ & & \\
\hline KB4-8GS1 & & & & & 0 & 0 & & & 0 & & & \\
\hline KB4-20GS1 & 0 & & & 0 & 0 & & & & 0 & & & \\
\hline KB4-22GS1 & $\bigcirc$ & & & 0 & 0 & $\bigcirc$ & ○ & $\bigcirc$ & & 0 & $\bigcirc$ & $\bigcirc$ \\
\hline KB4-24GS1 & 0 & & & & 0 & & & & & & & \\
\hline S2_Rev & & 0 & & 0 & 0 & & & & & 0 & & 0 \\
\hline S17_Rev & 0 & & & 0 & & 0 & & & & & 0 & 0 \\
\hline S40_Rev & & & 0 & 0 & & 0 & 0 & & 0 & 0 & 0 & \\
\hline SRNRN & & 0 & & & & 0 & 0 & 0 & & 0 & 0 & 0 \\
\hline
\end{tabular}

${ }^{1)}$ ○はS-SAP 増幅産物の配列から予想された長さの断片が増幅したことを示す。 
クローニング結果も活用することにより, 開発中の蒸切 干し新品種候補を対象に，別の品種が偶然同じ「挿入有」 のパターンを示す確率は事実上 0 (零) と見なせる DNA 鑑定方法として実用化することとしている.なお， Rtsp1 レトロトランスポゾンには，ゲノム中に転移活性を維 持した配列が存在するが，9種類のプライマーとも，親 子関係にない複数の品種で PCR 増幅が見られることか ら，このような挿入部位は増幅が見られた品種の共通祖 先で発生した転移に由来し，分析したクローンに颃いて 偶然生じた転移由来の品種内多型を示すものではないと いえる.

作物の品種識別の手法開発は, 現在, 機器分析による 自動化が可能で，再現性，多型性に優れた SSR マーカー を用いたものに移ってきているとされる(福岡 2004)。こ の方法は，マイクロサテライトと呼ばれる短い配列が反 復して現れるゲノム上の部分を PCR により増幅し検出 するものである。 このような反復数は変異が生じやす く，多型の出現頻度が高い。 また，反復配列に隣接する 固有の領域にプライマーを設定して PCR を行らため, SSR マーカーはそれぞれ特定の遺伝子座として，また， 反復数の違いは対立遺伝子として扱うことができる。 反 復配列は，植物のゲノム上の様々な場所に多数存在する ので，複数の遺伝子座に打ける複数の対立遺伝子の組み 合わせによって，品種を識別する．SSR は共優性マ一 カーであり，2 倍性の作物では，各遺伝子座に扣いて，同 型接合と異型接合の遺伝子型が電気泳動によるバンド パターンやキャピラリー電気泳動での検出（表現型）か ら特定できる。しかし，作物でも多く見られる倍数体て は，異型接合の表現型から対立遺伝子の組み合わせを特 定することは極めて困難であり，品種識別には，2 倍性 の植物と比べてより多数の遺伝子座の情報を組み合わせ る必要がある。しかし，6倍性で強い自家不和合性のた めに異質接合性の高いサッマイモに拈いては，SSR 遺伝 子座の多くは，識別効率が低いと考えられる。

これに対して，レトロトランスポゾンのゲノム特定部 位への挿入の有無をPCRによって判定する本報告の方 法は，優性マーカーであり，分析対象の倍数性や異質接 合性の影響を受けることがないものと考えられる．品種 間で多型を示す挿入部位は，今回の実験では，一回のSSAP 分析により多数見いだされている。そのような挿入 部位は，本報告の方法に従い，効率よくクローニングす ることが可能であるので，品種の識別性の確保や精度向 上の必要性に応じて必要なマーカーの数を確保できるも のと考えられる。な拈，S-SAPの 2 回目のPCRに捈い て，アダプタープライマーとしてアデニンを付加した Mse I プライマーを使ったが，付加する塩基を別のもの にすると，増幅断片のパターンが全く異なることから， 品種間で多型を示す挿入部位は，多数存在するものと考 えられる（Tahara et al. 2004）。

染色体の特定部位に拈けるレトロトランスポゾン挿入
の品種間多型を PCR により判定し品種識別を行ら本報 告の方法には，様々な利点がある。まず，(1)プライマー を宿主側の配列と LTR 配列の接する部分に設計すれば, PCR 増幅の対象を，両プライマーを合わせた長さ程度の 小さなものとすることも可能であり, PCR の極めて高い 検出能力を考慮すると, DNA が断片化した加工品の分析 に沶いては最も適したDNA 分析方法である。(2)レトロ トランスポゾンと宿主といら連続性が期待されない配列 間の PCR であり，プライマーの配列特異性を高めること で，検出の確からしさと再現性を十分確保できる。(3)増 幅される断片の長さではなく増幅の有無を検査するた め，簡便な電気泳動により正確な判定が可能である. (4) LTR 配列は共通であり, 本実験の Ext_R プライマーのよ らに，一種類のプライマーで対応できるらえ，挿入を受 けた宿主側の配列の間に共通性は予想されないことか ら，宿主側配列のプライマーを挿入場所ごとに増幅断片 長が異なるよらに設計することで，一度に複数の挿入場 所を調査する Multiplex PCR とすることができる（図 6). なお，(1)の特徵とも関連するが，前述の様に，Rtsp-1 の LTR 配列は，5' 末端側のU3 領域では配列が多様であり， R および 3' 末端の U5 領域では配列が非常に高く保存さ れている. 本研究では，5'末端側の挿入部位をクローニ ングしたので, このような理由から, LTRの共通プライ マーとしては， R 領域の配列を用いる必要があった（図 4).しかし，3' 末端側の挿入部位を用いる場合には，宿 主側の配列と隣接する LTR の $3^{\prime}$ 末端側に共通プライ マーを設計できる，さらに，(5)優性マーカーであり，そ れぞれの遺伝子座（挿入位置）に打ける対立遺伝子の種 類は, 有・無の 2 種類であるが, 新品種など, 特定の品種 を識別したい場合には，その品種に执いて対立遺伝子の

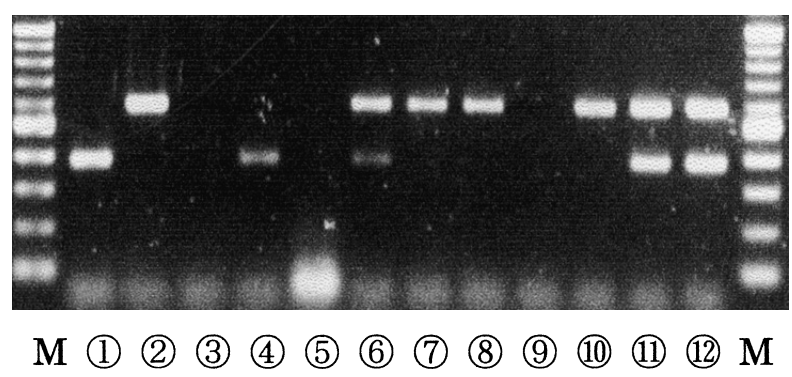

図 6. S-SAP 増幅産物の配列を基に宿主上の配列に設計したプ ライマー (S17 Rev 扎よび SRNRN) とレトロトランスポ ゾン Rtsp-1 の末端反復配列上のプライマー (Ext_R) を混 合し，葉から抽出した DNA を鋳型として行ったマルチ プレックス PCRによる増幅産物の品種間多型.

$\mathrm{S} 17 \mathrm{Rev}$ と Ext R または SRNRN と Ext R のプライマー 組み合わせによる期待増幅産物 (383 bp または 591 bp)が 1 回のマルチプレックス PCR により検出されている. M: サイズマーカー (100 bp ラダー), (1)へルシーレッド, (2)畑薯 6 号, (3)宇薯 2 号, (4)タマユタカ, (5)タマオトメ, (6)関東 119 号, (7)関東 120 号, (8)九州 122 号, (9)九州 127 号，(10九州 139 号，(11)泉 13 号，(12)沖縄 100 号 
出現頻度が低くなる挿入位置（その品種には存在するが 他の品種ではあまり存在しない，あるいは，その逆）を S-SAP により探してPCR マーカー化することで, 少ない マーカー数でも, 別の品種が偶然同じマーカー型を示す 危険率を低く抑兄，識別性を高めることができる。

LTR 型のレトロトランスポゾンは，今まで調査された 範囲では，全ての高等植物に存在して招り，主要な作物 については，個別の配列が多数単離され，命名されてい る (Johns et al. 1985, Manninen and Schulman 1993, Laten et al. 1998, Kumekawa et al. 1999)． LTR 型のレトロトラ ンスポゾンのうち，Ty1-Copia 型に分類されるものにつ いては，逆転写酵素領域に存在する保存アミノ酸配列を ターゲットとする PCR により，同酵素領域の配列が多数 の植物から単離されている (Voytas et al.1992, Hirochika et al. 1992). 従って, レトロトランスポゾンの全長配列 が調べられていない作物であっても，DNA データベース に打いて既知の，あるいは，新たに逆転写酵素領域の配 列を同定すれば, その延長配列を単離する TAIL（Thermal Asymmetric InterLaced) PCR (Liu et al. 1995), Suppression PCR（Siebert et al. 1995） やその他の方法（Pearse et al. 1999）により，末端の LTR 配列までを同定することがで きる。レトロトランスポゾンの挿入位置を利用する本報 告の方法は, マーカー開発に, 以上のような研究が必要 ではあるが，特に，高次倍数性で品種の異型接合性が高 い栄養繁殖性の作物, DNA が断片化した加工品の分析が 必要なものなどにおいては，高い識別性を有する優れた マーカーとなるものと考光られる。

\section{謝 辞}

本研究に当たり, 独立行政法人農業・生物系特定産業 技術研究機構作物研究所畑作物研究部甘しょ育種研究室 中谷誠室長には，蒸切干し用育成系統なぞのご提供を頂 くとともに，貴重なご助言を賜りました。 また，本研究 は, 平成 15 年度先端技術を活用した農林水産研究高度化 事業「蒸切干し用甘しょの国際競争力強化に必要な高品 質化に関する技術開発」拉よび第 24 回財団法人両備檉 園記念財団生物学研究助成の助成により行いました。 こ こに記して深く感謝の意を表します。

\section{引用文献}

独立行政法人農林水産消費技術センター (2002) JAS 分析試験八 ンドブック遺伝子組換え食品検査・分析マニュアル改訂第 2 版基本操作編.

Flavell, A.J., M. Knox, S.R. Pearce and T.H.N. Ellis (1998) Retrotransposon-based insertion polymorphisms (RBIP) for high throughput marker analysis. Plant Journal 16: 643-650.

Fukuchi, A., F., Kikuchi and H. Hirochika (1993) DNA fingerprinting of cultivated rice with rice retrotransposon probes. Jpn. J. Genet. 65: 195-204.
福岡浩之 (2004) 野菜の DNA 品種識別法確立に向けての技術的 問題点とその方策. 農業执よび園芸 79: 175-179.

Grandbastien, M.A., A. Spielmann and M. Caboche (1989) Tnt1, a mobile retroviral-like transposable element of tobacco isolated by plant cell genetics. Nature 337: 376-380.

早川孝彦（1997）タバコの DNA・RNA 単離法. “新版植物の PCR 実験プロトコール” 島本功, 佐々木卓治監修. 秀潤社, 東京. 49-56

Hirochika, H. (1993) Activation of tobacco retrotransposons during tissue culture. EMBO J. 12: 2521-2528.

Hirochika, H., A. Fukuchi and F. Kikuchi (1992) Retrotransposon families in rice. Mol. Gen. Genet. 233: 209-216.

Hirochika, H., K. Sugimoto, Y. Otsuki, H. Tsugawa and M. Kanda (1996) Retrotransposons of rice involved in mutations induced by tissue culture. Proc. Natl. Acad. Sci. USA 93: 7783-7788.

猪飼のぞみ・松田智明・中谷 誠・新田洋司 (2002) 蒸切干し サッマイモに打ける「シロタ」の構造的特徵と白色不透明化 の要因. 日本作物学会関東支部会報 17: 56-57.

Johns, M.A., J. Mottinger and M. Freeling (1985) A low copy number, copia-like transposon in maize. EMBO J. 8: 1093-1102.

Kumar, A. and J.L. Bennetzen (1999) Plant retrotransposons. Annu. Rev. Genet. 33: 479-532.

Kumar, A. and H. Hirochika (2001) Application of retrotransposons as genetic tools in plant biology. Trends Plant Sci. 6, 127-134.

Kumekawa, N., H. Ohtsubo, T. Horiuchi and E. Ohtsubo (1999) Identification and characterization of novel retrotransposons of the gypsy type in rice. Mol. Gen. Genet. 260: 593-602.

Laten, H.M., A. Majumdar and E.A. Gaucher (1998) SIRE-1, a copia/ Tyl-like retroelement from soybean, encodes a retroviral envelope-like protein. Proc. Natl. Acad. Sci. USA 95: 6897-6902.

Liu, Y.G., N. Mitsukawa and T. Oosumi. (1995) Efficient isolation and mapping of Arabidopsis thaliana T-DNA insert junctions by thermal asymmetric interlaced PCR. Plant Journal 8: 457-463.

Manninen, I. and A.H. Schulman (1993) BARE-1, a copia-like retroelement in barley (Hordeum vulgare L.). Plant Mol. Biol. 22: 829-846.

野澤 真（2004）植物品種保護制度の概要．農業および園芸 79: $105-110$.

Pearce, S.R., C. Stuart-Rogers, M.R. Knox, A. Kumar, T.H.N. Ellis and A.J. Flavell (1999) Rapid isolation of plant Ty1-copia group retrotransposon LTR sequences for molecular marker studies. Plant Journal 19: 711-717.

Siebert, P.D., A. Chenchik, D.E. Kellogg, K.A. Lukyanov and S.A. Lukyanov (1995) An improved PCR method for walking in uncloned genomic DNA. Nucleic Acids Res. 23: 1087-1088.

Tahara, M., T. Aoki, S. Suzuka, H. Yamashita, M. Tanaka, S. Matsunaga and S. Kokumai (2004) Isolation of an active element from a high-copy-number family of retrotransposons in the sweetpotato genome. Mol. Genet. Genomics 272: 116-127.

Vernhettes, S., M.A. Grandbastein and M. Casacuberta (1998) The evolutionary analysis of the Tnt1 retrotransposon in Nicotiana species reveals the high variability of its regulatory sequence. Mol. Biol. Evol. 15: 827-836.

Voytas, D.F., M.P. Cummings, A. Konieczny, F.M. Ausubel and S.R. Rodermel (1992) copia-like retrotransposons are ubiquitous among plants. Proc. Natl. Acad. Sci. USA 89: 7124-7128.

Waugh, R., K. McLean, A.J. Flavell, S.R. Pearce, A. Kumar, B.B.T. Thomas and W. Powell (1997) Genetic distribution of Bare-1- 
like retrotransposable elements in the barley genome revealed by sequence-specific amplification polymorphisms (S-SAP). Mol. Gen. Genet. 253: 687-694.
矢野 博 (2004) DNA 多型分析による品種識別の可能性一植物 に打ける DNA 多型検出技術とその応用一. 農業および園 芸 79: 131-136.

\title{
Cultivar Identification Technique Applied for Hoshi-imo, Steamed and Dried Sweetpotato Slices, Based on Retrotransposon Insertion Polymorphisms
}

\author{
Natsuko Ooe ${ }^{1)}$, Makoto Tahara ${ }^{1)}$, Hiroki Yamashita ${ }^{1)}$, Yuu Marutani ${ }^{1)}$ and Toshikazu Kuranouchi²) \\ ${ }^{1)}$ Faculty of Agriculture, Okayama University, Okayama 700-8530, Japan \\ ${ }^{2}$ National Institute of Crop Science, National Agriculture and Bio-oriented Research Organization, Tsukuba, Ibaragi 305-8518, \\ Japan
}

In order to prevent patented new cultivars from unauthorized cultivation, a DNA analysis technique aimed at identifying sweetpotato cultivars used for making Hoshi-imo, steamed and dried sweetpotato slices, was developed based on retrotransposon insertion polymorphisms. Insertion sites of the Rtsp-1, an LTR (Long Terminal Repeat) retrotransposon identified in sweetpotato genome, were displayed by the S-SAP (sequence-specific amplification polymorphism) technique for 12 cultivars, which included traditional cultivars and advanced breeding lines for Hoshi-imo production. The S-SAP products, which were present for at least one cultivar but were absent for the others, were cloned and sequenced. PCR primers were designed on the host sequences adjacent to Rtsp- 1 insertion. Absence or presence of PCR products of nine cloned Rtsp- 1 insertion sites could successfully differentiate the 12 cultivars. An anion-exchange column was able to isolate DNA from Hoshi-imo, although the steaming process had led to the formation of DNA fragments with small sizes. The PCR for Rtsp- 1 insertion sites, nevertheless, amplified the expected products from Hoshi-imo DNA and correctly identified the cultivar used for Hoshi-imo production.

Key Words: Ipomoea batatas, retrotransposon, DNA marker, cultivar identification, sweetpotato. 